\title{
Radiation effect in copper alloys for heat sink of high heat flux components of a fusion reactor
}

\author{
核融合炉高熱流束機器ヒートシンク銅合金の照射効果
}

\author{
Shiori ISHINO \\ Department of Nuclear Engineering, Tokai University, 1117, Kitakaname, Hiratsuka-shi, Kanagawa-ken, \\ 259-1292 Japan \\ TEL: 81-463-58-1211 (Ex.4153).FAX: 81-463-50-2017 E-mail: ishino@keyaki.cc.u-tokai.ac.jp \\ ( Received 25, November 1999 Accepted 4, April 2000)
}

\begin{abstract}
High strength high conductivity copper alloys will be used for heat sink materials of a high heat flux component of a fusion reactor. High energy neutron irradiation on these materials will cause atomic displacements and nuclear transmutation, which will lead to degradation of thermal conductivity and mechanical properties of the materials. These effects will be briefly reviewed with special emphasis on synergistic effects of displacements and transmutation. It should be kept in mind that even pure copper will be transformed into $\mathrm{Cu}-\mathrm{Ni}-\mathrm{Zn}$ alloy by fusion neutron irradiations. This effect on the thermal conductivity and mechanical properties cannot be ignored for long term use of copper alloys in neutron irradiation environment.

We have been utilizing $\mathrm{Cu}-\mathrm{Ni}-\mathrm{Zn}$ alloys to simulate the effect of nuclear transmutation. Displacement damage with fusion neutrons has been simulated by ion irradiation with $2.4 \mathrm{MeV}$ copper self ions. Results of these experiments will be summarized.
\end{abstract}

Keywords : Copper, copper alloy, Nuclear transmutation, Thermal conductivity, Hardness change, Neutron irradiation, Ion irradiation,

\section{INTRODUCTION}

ダイバータ、リミターなどの核融合炉のプラズマ対向 高熱流束機器のヒートシンク材料は、高い熱伝導度と高 い熱流束によって生じる熱応力に酎える強度が要求され ることからいわゆる高力高伝導銅合金の使用が考えられ ている。例えば国際熱核融合炉(ITER)では第一壁および リミターのヒートシンク材としてはアルミナ粒子分散型 銅合金（以下Dispersion Strengthened Copper alloy の略称 として DSーCuと表す)、ダイバータ用には Cu-Cr-Zr 合 金のような析出強化型銅合金（以下 Precipitation hardened Copper alloy の略称として PH-Cuと表す) の使 用が提案されている。1、2

ところで、これらの機器はプラズマに近い位置にある ことから当然核融合中性子の照射を受ける。その結果 として原子のはじき出しと共に核変換が起こる。核変換 としては従来 $(\mathrm{n}, \alpha)$ および $(\mathrm{n}, \mathrm{p})$ 反応の結果生じるへリ ウムおよび水素の效果がいろいろと調べられてきたが、 ヒートシンク用銅合金ではいわゆる金属核変換生成物 (Metallic transmutants) が熱伝導度劣化の観点から重
要である。DS-Cuにしても PH-Cuにしても、高伝導性を 得るためにはマトリックスの固溶元素が少ないことが必 要であるが、この条件は純銅でさえも中性子照射によっ

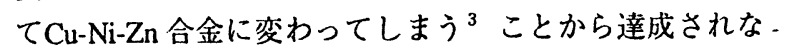
くなり、使用条件はフルエンスと共に狭まって行く。ヒ 一トシンク材の使用限界を明らかにするためにも、中性 子照射による熱伝導度低下と強度变化を知る必要がある。

この変化の原因は上述のようにはじき出しと核変換で あるが、その相乗効果が重要である。しかしIFMIF

(International Fusion Materials Irradiation Facility)のよう な核融合炬材料照射用強力中性子源が存在しない現状で は、4 原子炬中性子照射やイオン照射に頼らざるを得な い。本論文では今までに行われた原子炉照射実験と我々 の結果を含めいくつかのイオン照射実験の結果について まとめる。

\section{CALCULATION OF TRANSMUTATION}

純銅が中性子照射環境に曝された場合の核变換反応の 主なものには Fig.1に示すようなものがある。 
Greenwood らはREACコードを用いて核融合炉 STARFIRE（概念設計）の第一壁条件で銅の核変換生成 物を計算した。 ${ }^{3}$ その後さらに原子炉FFTF（炉心中央）、 HFIR（炉心周辺照射領域PTP: Peripheral Test Position） についても計算が行われており、dpaに対してNiおよび $\mathrm{Zn}$ の生成量を Fig.2 に示す。.5 Co も微量生成するが、 この図では無視されている。

\section{REVIEW OF IRRADIATION DATA}

\section{A. Mechanical properties}

ITER におけるヒートシンク銅合金の使用条件は、温度 150- $250^{\circ} \mathrm{C}$ 、照射量 $10 \mathrm{dpa}$ 以下、損傷速度 $3.3 \times 10^{-7} \mathrm{dpa} / \mathrm{s}$ という值が示されている。 ${ }^{6}$ これは最適条件というより は現状の銅合金の設計ウインドウとしてはこの程度に留 める必要があるという意味であろう。照射による機械的 性質の変化についても SM-2, DR-3, HFR(Petten)などの原 子炉、電子線あるいはイオン加速器などによって調べら れているが、照射温度はほとんど $350^{\circ} \mathrm{C}$ 以下で、照射量 もほとんど 1dpa 以下である。

ヒートシンク銅合金の照射に関連した問題点としては、 スエリング、照射クリープ、低温照射脆化等が挙げられ る。 ${ }^{7}$ 一方、非照射でも軟化温度は $\mathrm{PH}-\mathrm{Cu}$ で $300^{\circ} \mathrm{C}$ 程 度、DS-Cu でも $400^{\circ} \mathrm{C}$ 程度であり、低温照射脆化を考え ると、使用温度範囲はPH-Cu で $180-280^{\circ} \mathrm{C}$ 程度、DS-Cu でも $180-350^{\circ} \mathrm{C}$ 程度と考えられる。7

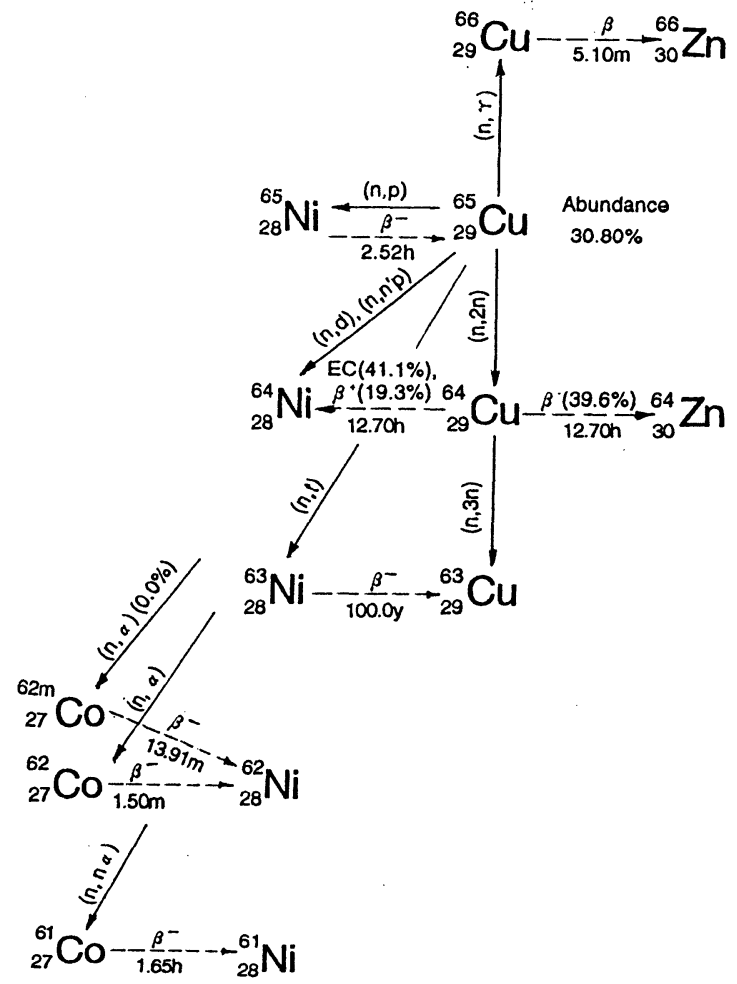

FIG.1. Nuclear transmutation reactions with regard to copper in a neutron environment.

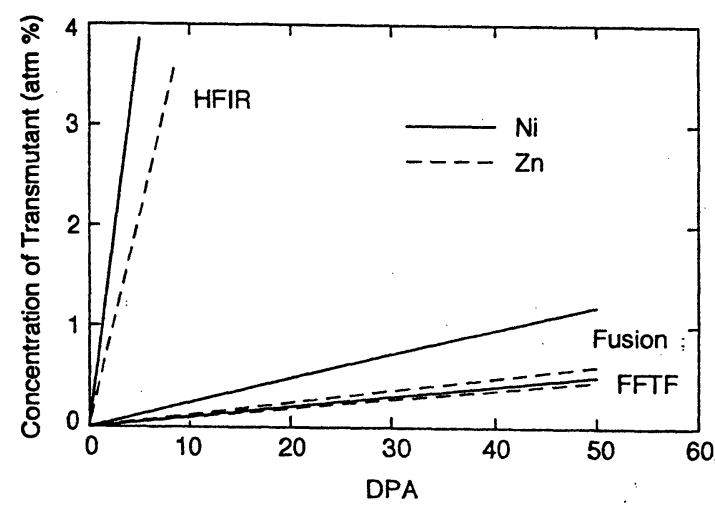

FIG.2. Accumulation of transmutation products in copper in various neutron irradiation environments as a function of dpa. 5

Fabritsiev らはDS-Cuおよび PH-CuについてSM-2 炬で $\sim 100^{\circ} \mathrm{C}$ から $300^{\circ} \mathrm{C}$ 範囲で約 $5 \mathrm{dpa}$ までの照射による引 張特性の変化を調べている。 ${ }^{8}$ その結果 $150^{\circ} \mathrm{C}$ 以下では 延性低下が顕著であり、その傾向はすでに0.001dpa で認 めら㣗、0.1dpaでは飽和を示す。

Fabritsievらはさらに、高強度の $\mathrm{CuNiBe}, \mathrm{CuCrNiSi}$ 合 金を $\mathrm{CuCrZr}$ 合金と比較しつつ SM-2 炬を用い $150^{\circ} \mathrm{C}$ およ び $300^{\circ} \mathrm{C} て ゙ 0.2 \mathrm{dpa}$ まで照射し、引張特性の変化を調べて いる。 ${ }^{9}$ その結果 $\mathrm{CuNiBe}$ おび CuCrNiSi合金では脆化 および破壊応力の著しい低下が見られる。 ${ }^{9}$ 非照射の

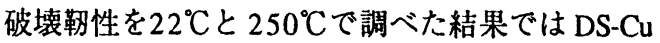
(GlidCopAl-15, Al-25) および CuNiBe 合金では $250^{\circ} \mathrm{C} に お ~$ ける破壊勒性の低下が著しいのに、 $\mathrm{CuCrZr}$ 合金では低下 はさほど大きくはない。10 CuCrZr 合金およびGlidCop $\mathrm{Al}-25$ をDR-3炬で $200^{\circ} \mathrm{C}$ およ゙ $350^{\circ} \mathrm{C} て ゙ ~ 0.3 \mathrm{dpa}$ まで照射

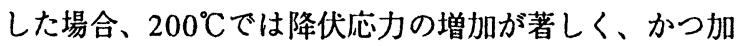

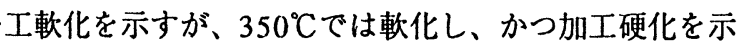
す。 ${ }^{11}$ 破壊勒性はGlidCop Al-25では照射により著しく

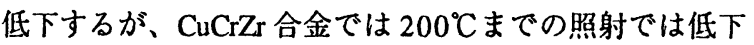
はさほど大きくない。11この傾向は照射量を2dpa 位ま で上げた最近のデータでもあまり変わらない。12

\section{B. Thermal conductlvity}

銅および銅合金のように電気伝導度の大きな金属合金 では、熱伝導度はほとんど電子熱伝導度によってきまり、 電気抵抗, $\rho$,と熱伝導度, $\kappa$, , 間には Wiedemann-Franz の法則：

$$
\kappa_{\mathrm{e}} \cdot \rho=\mathrm{LT},
$$

が成り立つと考えて良い。ここで Lはローレンツ数であ る。このため、熱伝導度の測定はほとんど電気抵抗測定 によって行われている。

Fabritsiev らは純銅およびDS-Cuにひいて SM-2炉で照 射を行い、電気抵抗の変化を测定している。13 核変換 
(a)

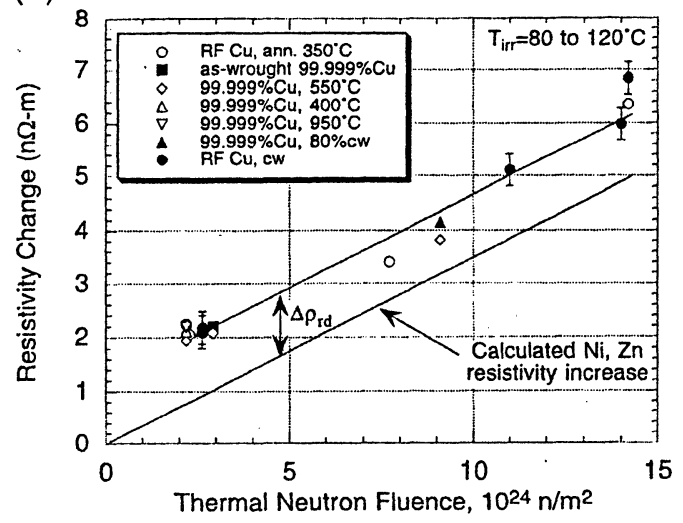

(b)

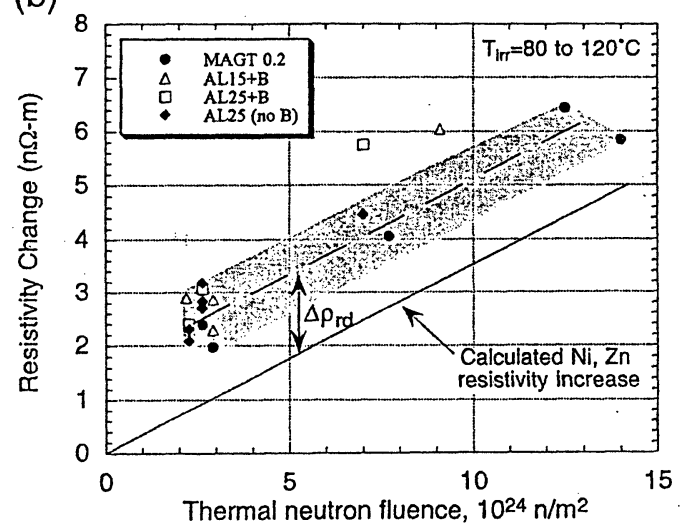

FIG.3. Change in electrical resistivity in pure copper and some DS-Cu alloys as a function of thermal neutron fluence. Note that radiation damage component saturates in early stage of irradiation. ${ }^{13}$

は熱中性子により起こると考元、熱中性子フルエンスに 対して電気抵抗変化を示したのがFig.3である。Niおよ び $\mathrm{Zn}$ の電気抵抗寄与の線形加算性を仮定すると、全電 気抵抗变化、 $\Delta \rho_{\text {lotal }}$ は、はじき出し損傷および核変換 原子の寄与の和として

$$
\Delta \rho_{\text {lotal }}=\Delta \rho_{\mathrm{t}}+\Delta \rho_{\mathrm{tr}}
$$

と書くことができ、さらに核変換の寄与は $\mathrm{Ni}$ および $\mathrm{Zn}$ の寄与の和として

$$
\Delta \rho_{\mathrm{r}}=\Delta \rho_{\mathrm{Ni}}+\Delta \rho_{\mathrm{Zn}}
$$

と書けることになる。 $\mathrm{Ni}$ および $\mathrm{Zn}$ の濃度は熱中性子フ ルエンスに比例するとし、またFig.3からはじき出し損傷 部分は $0.1 \mathrm{dpa}$ 程度で飽和すると考えられるので（飽和値 $\sim 1.2 \mathrm{n} \Omega \cdot \mathrm{m})$

$$
\Delta \rho_{\text {tolal }}=\Delta \rho_{\mathrm{d}}+\Delta \rho_{\mathrm{t}}=1.2 \mathrm{n} \Omega \cdot \mathrm{m}+\mathrm{K} \phi_{\mathrm{th}} \mathrm{t} .
$$

ここで $\mathrm{K}=3.5 \mathrm{n} \Omega \cdot \mathrm{m} / 10^{25} \mathrm{n} / \mathrm{m}^{2}, \phi_{\text {th }}$ は熱中性子フラッ クス、tは照射時間である。

ところで、Fig.4は照射温度の関数として (a) 純銅およ (a)

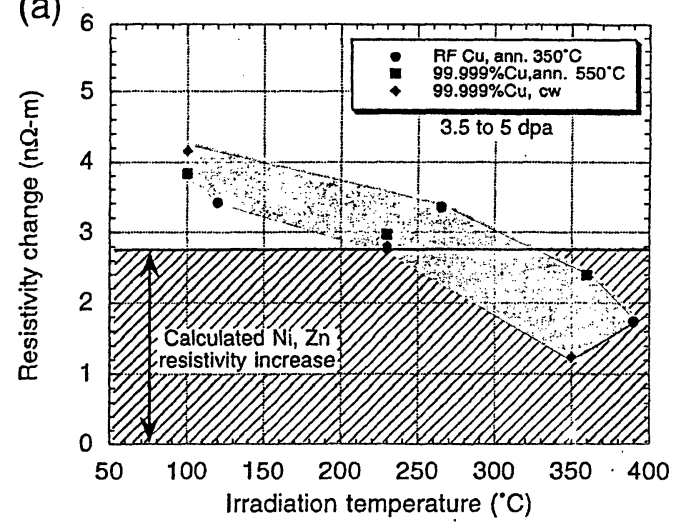

(b)

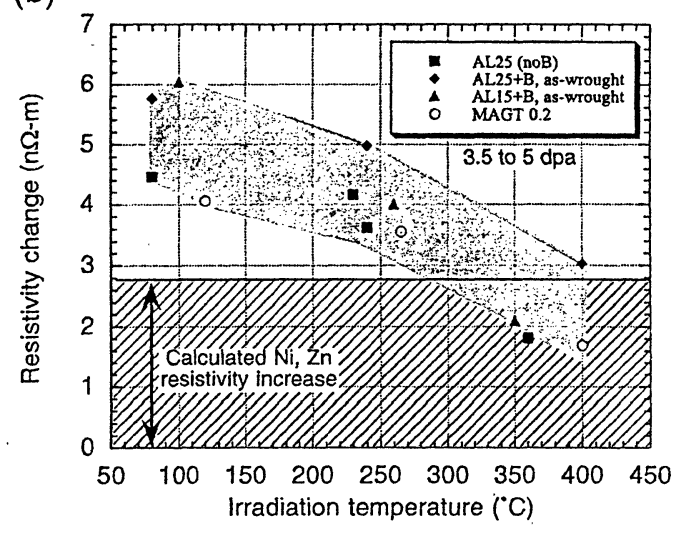

FIG.4. Change in electrical resistivity in (a) pure copper and (b) DS-Cu alloys as a function of irradiation temperature. Note that the total electrical resistivity change becomes less than that for trasmutants in solid solution above $250^{-} 300^{\circ} \mathrm{C} .{ }^{13}$

び (b) DS-Cuの電気抵抗変化を示しているが、重要なこ とは、高温照射で久宿のアニールが起こることは当然と

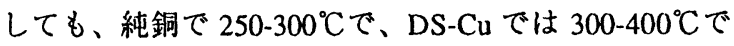
電気抵抗変化が核変換生成物単独の寄与を下回ることで ある。このことは核変換生成元素が固溶体として存在す るのではなくなることを意味しており、はじき出しによ る照射欠陥と核変換原子の相互作用があることを示して いる。相互作用の内、電気抵抗を減少させることに奇与 する機構としては,

1）核変換生成元素の欠陥クラスタ、転位、粒界などへ の搪散、

2 ) 欠陥シンクへの照射誘起偏析 などが考えられる。一方、電気抵抗を増加させる機構と しては

1）雔との複合欠陥の形成（電気抵抗を減少させる場 合も考えられる)、

2) 析出物、分散粒子のカスケード等による反跳固溶化 (Ballistic resolution) および再析出（減少の場合もあり） 
等が考えられる。

これらの相互作用については次項の組織変化および我タ の実験結果に関連した検討の中でさらに議論する。

\section{Microstructural evolution}

中性子照射によるミクロ組織変化については、主とし てボイドスエリングの観点から比較的高温重照射の条件 でFFTFや HFIR などの原子炉を用いて研究が行われて きた。 ${ }^{14-16}$ また、核変換生成物の影響を調べる目的で 銅に Ni や Znを合金化させた試料を用い、原子炬で生成 する $\mathrm{Ni}$ や Znと併せて $\mathrm{Ni} / \mathrm{dpa}$ および $\mathrm{Zn} / \mathrm{dpa}$ 比を系統的 に変化させる試みもなされている。16これによって、 $\mathrm{He} / \mathrm{dpa}$ も変化することが検討されている。 ${ }^{17}$ さらにイ オン加速器を用いて、Cu 自己イオンのみならず Niイオ ンを用いて核変換生成元素とはじき出し損傷の導入を同 時に行う試みもなされるようになった。 ${ }^{18}$

ごれまでの䊅果を要約すると、まずNi の効果としては， 1) 格子間原子型転位ループの核形成を促進し、高密度 の転位を保つためボイドスエリングを助長する。

2 ）点欠陥のシンクである粒界やボイド表面に偏析を起 こす。

一方、Znについては,

1）格子間原子型転位ループの形成に対する影響は少な いと考えられる。

2 ）粒界のZn濃度が低下する。これは照射下で粒界に流 入する空格子点と逆方向にZnが移動することを意味する。 空格子点はZnと選択的に結合することによりその易動度 が低下し、低温度領域のスエリングが抑制され、スエリ ングピークが高温側にシフトする。

\section{EXPERIMENTAL INVESTIGATIONS AT TOKAI UNIVERSITY}

\section{A. Introduction}

本章では標題に関して東海大学で行われている研究の 概要を述べる。その主要な部分は1999 年 10 月、米国で 開かれた第 9 回核融合炉材料国際会議（ICFRM-9）にお いて報告された。19

第 1 章に述べたように核融合炉では発生するエネルギ 一の大半が中性子の運動エネルギーとして放出されるの で、核融合炉材料、とりわけプラズマに近いいわゆる炬 心材料は中性子照射効果に対する検討は避けて通れない。 炉心プラズマに近い高熱流束機器のヒートシンク材料と しての銅合金も中性子照射によるはじき出し損傷ととも に、同時に発生する核变換生成物の效果を調べる必要が あるが、核融合炉材料照射用強力中性子源が存在しない 今日、この相乗効果を調べることは極めて困難である。 そのための模擬手段として、核変換生成元素を予め含ま せた合金を用いて、実験条件を制御できるイオン照射を 利用して、はじき出し/核变換相乗効果を調べるのが我々 の研究の目的である。

\section{B. Experimental}

\section{Specimen}

上述のようにSTARFIREの第一壁条件 $\left(3.6 \mathrm{MW} / \mathrm{m}^{2}\right)$ では, 5 年間の使用で純銅は $\mathrm{Cu}-5.4 \% \mathrm{Ni}-2.4 \% \mathrm{Zn}-0.3 \% \mathrm{Co}$ 合金 に変化する。これはヒートシンク材としては極端な条件 であるが、核变換効果を強調して調べるため、この值を 参考にして、Table 1 のような核变換模擬合金を融製し た。Coは微量であるとして無視することとした。

合金はアルゴン雲囲気中で水冷銅坩堝を用い二重アー ク融解により融製した。襄鉛の添加には高純度

$\mathrm{Cu}-40 \% \mathrm{Zn}$ 母合金を用いたが、溶湯温度を可能な限り低 く保っても目標通りの亜鉛量を添加することは極めて難 しかった。合金は成形後、中間焼鈍なしに冷間圧延によ り厚さ $0.1 \mathrm{~mm}$ の板とし、両端および中間部から分析用試 料を採取した。また、この板から電気抵抗測定用および 硬さ測定用試料を切り出し、電気抵抗測定試料について は真空中、硬さ測定用試料についてはアルゴン気流中で $800^{\circ} \mathrm{C} 1$ 時間の焼鈍を行い、最終的には電解研磨仕上げ とした。

\section{Hardness measurement}

マイクロ硬さ測定用の試料は $10 \mathrm{~mm} \times 10 \mathrm{~mm}$ 又は $4 \mathrm{~mm}$ x 13mm（各厚さ $0.1 \mathrm{~mm}$ ）に成形したものを用いた。マ イクロ硬さ測定は島津製作所のナノインデンター（島津 DUH-201型）および ERIONICS ENT-1100s 型動的マイク 口硬さ試験機を用いた。

DUH-201型の場合、ビッカース硬さ Hv は

$$
\mathrm{H}_{2}=189.10 \times \mathrm{P} / \mathrm{L}_{2}
$$

によって求めた。ここで $\mathrm{P}$ は荷重 $(\mathrm{mN}) 、 \mathrm{~L}_{2}(\mu \mathrm{m})$ は 圧痕の対角線長さである。一方、ERIONICS ENT-1100s 型の場合は、荷重 $\mathrm{P}$ と圧子侵入深さdの関係が求められ るが、A, B を P,dによらない材料定数として

$$
\mathrm{P} / \mathrm{d}=\mathrm{Ad}+\mathrm{B} 、 \mathrm{~A}(\mathrm{GPa})=0.287 \mathrm{Hv}
$$

の関係から硬さが求められる。20 両測定機から得られ た以、の值はよく一致することが確かめられた。

TABLE 1. Chemical composition of the specimen(wt.\%).

\begin{tabular}{llllll}
\hline Specimen & $\mathrm{Ni}$ & $\mathrm{Zn}$ & $\mathrm{Cu}$ & $\rho$ & $\mathrm{Hv}$ \\
\hline Pure Cu & 0 & 0 & 99.99 & $\bigcirc$ & $\bigcirc$ \\
$\mathrm{Cu}-3 \mathrm{Ni}$ & 3.03 & 0 & Bal.* & $\bigcirc$ & - \\
$\mathrm{Cu}-6 \mathrm{Ni}$ & 6.00 & 0 & Bal. & $\bigcirc$ & $\bigcirc$ \\
$\mathrm{Cu}-3 \mathrm{Zn}$ & 0 & $\mathrm{Tr}^{*}$ a) & Bal. & $\bigcirc$ & - \\
$\mathrm{Cu}-6 \mathrm{Ni}-3 \mathrm{Zn}$ & $\mathrm{NA}^{*}$ & $\mathrm{Tr}$ a) & $\mathrm{NA}$ & $\bigcirc$ & - \\
$\mathrm{Cu}-0.8 \mathrm{Zn}$ & 0 & 0.8 & Bal. & - & $\bigcirc$ \\
$\mathrm{Cu}-2.4 \mathrm{Ni}-3.6 \mathrm{Zn}$ & 2.4 & 3.6 & Bal. & - & $\bigcirc$ \\
$\mathrm{Cu}-4.5 \mathrm{Ni}-2.9 \mathrm{Zn}$ & 4.5 & 2.9 & Bal. & - & $\bigcirc$ \\
\hline
\end{tabular}

*Bal.=Balance, $\mathrm{Tr} .=$ Trace, NA=Not analysed, a) Dezincified 


\section{Electrical resistivity measurement}

熱伝導度を求めるための電気抵抗測定は通常の 4 端子 法によった。試料は測定精度を上げるため、幾何学形状 因子 (1/wt) を大きくするよう矩形波形状に切り出した。 ここで、電圧端子間実効距離 1 は $73.0 \mathrm{~mm} 、$ 幅 $\mathrm{w}$ は $1 \mathrm{~mm}$ 、厚さ $\mathrm{t}$ は $0.1 \mathrm{~mm}$ である。但し、相対測定精度は 高いものの、形状測定誤差に起因する絶対精度は $5 \%$ 程 度に留まる。测定機としては定電流電源としてKeithley Model 224、デジタルマルチメータとして Keithley Model 2001 を用いた。浮遊起電力を打ち消すため、各測定ごと に電流極性を反転させて測定を行った。

核変換模擬合金試料の電気抵抗を $25-500^{\circ} \mathrm{C}$ の温度範 囲で測定した。この結果から Wiedemann-Franzの法則に 基づいて熱伝導度に变換した。なお、イオン照射用には 絶縁基板上に銅を200-600nm蒸着した試料を作成したが、 照射結果については今後報告する予定である。

\section{Ion irradiation}

イオン照射は九州大学応用力学研究所の $1 \mathrm{MV}$ タンデト ロン加速器を用いた。21.22 適当なマスキングを用い硬さ 測定用試料に室温で $2.4 \mathrm{MeV} \mathrm{Cu}{ }^{2+}$ イオンを、0.05, 0.5, 5, $45 \mathrm{dpa}$ 照射した。ここで dpa は損傷ピークの值で表した。 Figure 5 にはTRIMコードで計算された銅中の $2.4 \mathrm{MeV}$ $\mathrm{Cu}^{2+}$ イオンの損傷分布を示す。

\section{Experimental results}

\section{Electrical resistivity due to solid transmutants}

Figure 6 に純銅、Cu-3Ni, Cu-6Ni, Cu-6Ni-3Zn(公称組 成)合金の電気抵抗の温度依存性を示す。 $25^{\circ} \mathrm{C}$ 純銅の電 気抵抗は文献値のそれとよく一致している。 ${ }^{23}$ 分析結 果によれば Niはほほ目標通りの組成となっているが、 電気抵抗の Ni 濃度依存性を Fig.7 に示す。 Ni の電気抵 抗寄与率は僅かに温度依存性を示すが、2 $5^{\circ} \mathrm{C}$ の值を文献 值と比較して Table 2 に示す。 ${ }^{24,25} \mathrm{Ni}$ とは対照的に $\mathrm{Zn}$ の電気抵抗寄与率は求めることができなかった。 Znを 添加した 2 種の合金の测定では、Znが検出されなかっ た公称Cu-3Zn合金の值は純銅とほとんど変わらなかった が、一方、 trace 程度の Zn しか検出されなかった公称 $\mathrm{Cu}-6 \mathrm{Ni}-3 \mathrm{Zn}$ ではCu-6Ni合金よりも高い電気抵抗を示し、 $\mathrm{Zn}$ の電気抵抗寄与率の文献值から逆算すると、約 $2.6 \%$ の Zn が含まれていることに相当することが判った。分 析はx 線マイクロアナライザーによって行っているので、 表面組成を測っていることになるが、電気抵抗はバルク を測っているので、後述の脱亜鉛現象があると表面とバ ルクで濃度が異なっている可能性もある。

\section{Temperature dependence of thermal conductivity}

熱抢よび電気伝導度の大きな金属・合金では、上述の ように Wiedemann-Franz の法則が成り立つので、Fig. 6 から電子熱伝導度を求めた。その結果を Fig. 8 に示す。

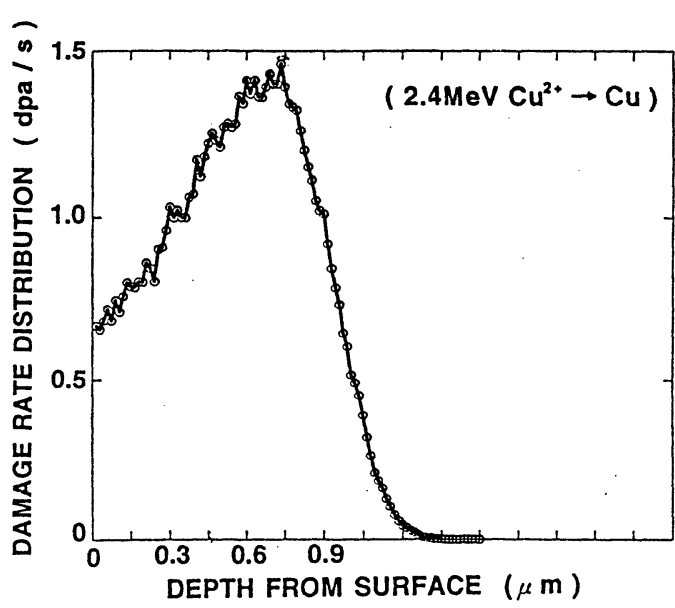

FIG.5. Damage distribution for $2.4 \mathrm{MeV} \mathrm{Cu}^{2+}$ ions into copper calculated by the TRIM code.

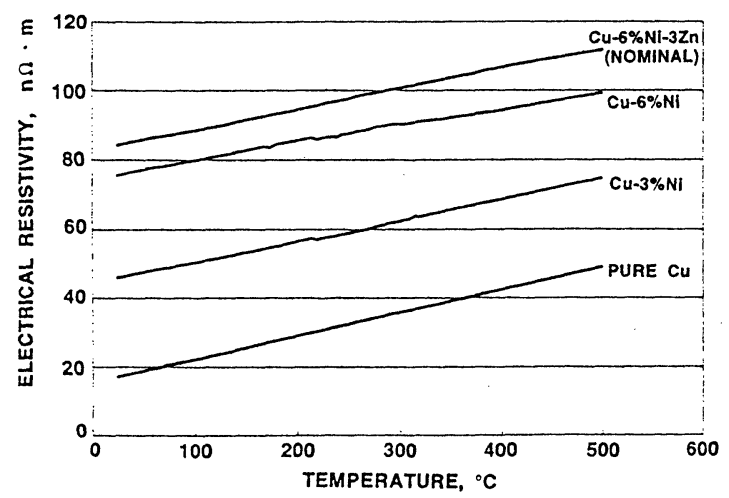

FIG.6. Temperature dependence of electrical resistivity for pure copper and $\mathrm{Cu}-3 \% \mathrm{Ni}, \mathrm{Cu}-6 \% \mathrm{Ni}$, $\mathrm{Cu}-6 \%$ ni-3\% Zn alloys between 25 and $500^{\circ} \mathrm{C}$.

TABLE 2. Electrical resistivity contribution of nickel and zinc in dilute copper alloy

\begin{tabular}{llll}
\hline Author & $\begin{array}{l}\text { Hoetal.(1983) } \\
(\mathrm{n} \Omega \mathrm{m} / \mathrm{wt} . \%)\end{array}$ & $\begin{array}{l}\text { Zinkle (1994) } \\
(\mathrm{n} \Omega \mathrm{m} / \text { at \%) }\end{array}$ & $\begin{array}{l}\text { Present } \\
(\mathrm{n} \Omega \mathrm{m} / \mathrm{at} \%)\end{array}$ \\
\hline $\mathrm{Ni}$ & 12.2 & 11.2 & $9.7 \pm 1.0$ \\
$\mathrm{Zn}$ & 2.7 & 3.0 & - \\
\hline
\end{tabular}




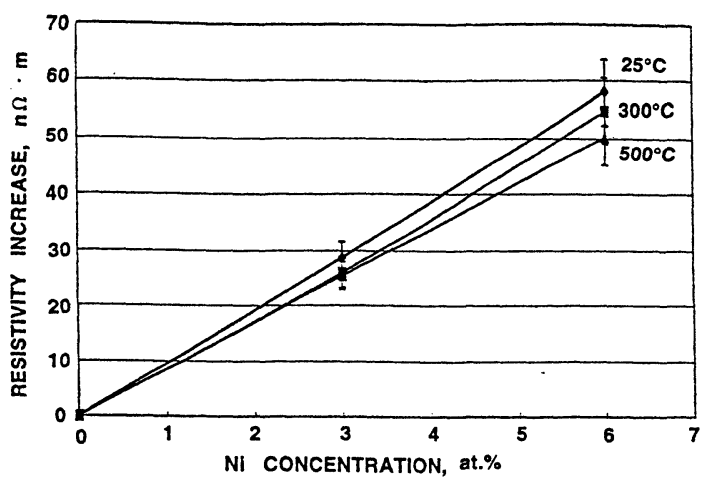

FIG.7. Nickel concentration dependence of resistivity at different temperatures.

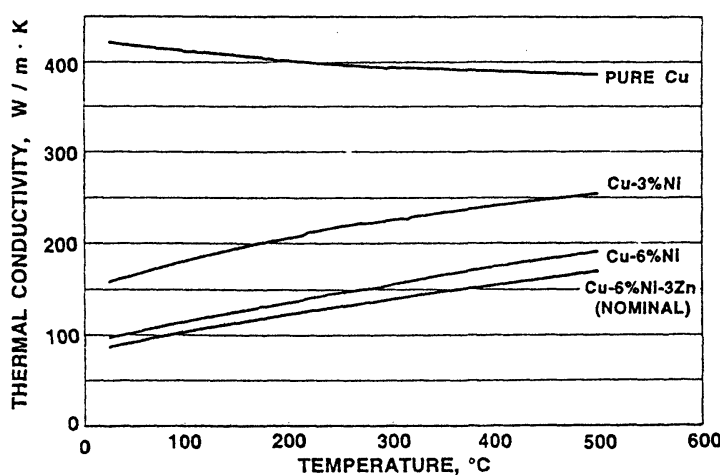

FIG.8. Thermal conductivity of pure copper, $\mathrm{Cu}-3 \% \mathrm{Ni}$, and $\mathrm{Cu}-6 \% \mathrm{Ni}-3 \% \mathrm{Zn}$ (nominal) alloys calculated from FIG.6.

TABLE 3. Summary of hardness data before and after ion irradiation for copper and several copper alloys.

\begin{tabular}{lccc}
\hline dpa & Pure Cu & Cu-6Ni & $\mathrm{Cu}-0.8 \mathrm{Zn}$ \\
0 & 49.2 & 56.1 & 70.0 \\
0.05 & 122.2 & 100.4 & 152.2 \\
0.5 & 141.7 & 144.8 & 168.8 \\
5 & 142.5 & 150.0 & 181.0 \\
\hline \multicolumn{4}{c}{} \\
\hline dpa & $\mathrm{Cu} 2.4 \mathrm{Ni3} .6 \mathrm{Zn}$ & $\mathrm{Cu} 4.5 \mathrm{Ni} 2.9 \mathrm{Zn}$ & $\mathrm{Cu} 6 \mathrm{Ni} 3 \mathrm{Zn}$ \\
0 & 109.1 & 90.7 & 54.1 \\
0.05 & 142.9 & 136.6 & 137.1 \\
0.5 & 166.6 & 174.3 & 166.1 \\
5 & 191.8 & 199.4 & 156.4 \\
\hline
\end{tabular}

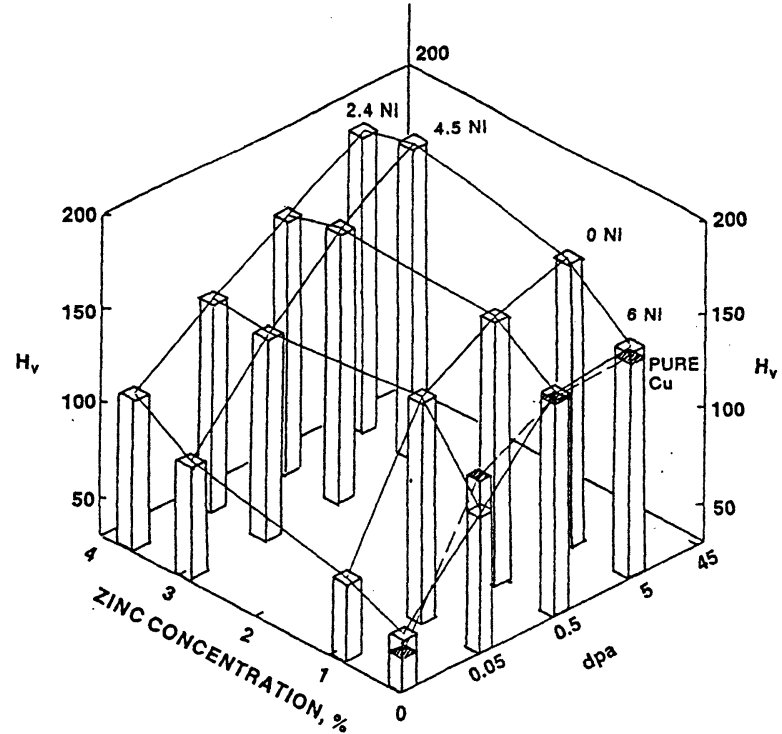

FIG.9. The change in hardness as a function of dpa and $\mathrm{Zn}$ concentration. Dpa values are represented by those at the damage peak for $2.4 \mathrm{MeV} \mathrm{Cu}$ ion irradiation.

図から明らかなように核変換生成物特にNiによって熱 伝導度の低下が起こることが判る。

\section{Hicrohardness measurements}

Table 3 にイオン照射前後の室温におけるマイクロビッ カース硬さをまとめて示した。ここで公称組成

$\mathrm{Cu}-6 \mathrm{Ni}-3 \mathrm{Zn}$ 合金ではCu-6Ni合金とほほ同様の硬さを示し たが、イオン照射の損傷領域は表面から約 $1 \mu \mathrm{m}$ である ことと脱垔鉛現象の可能性を考えると、電気抵抗測定と 硬さ测定の食い違いが理解できる。

照射前の硬さは Ni 量にはほとんど依存しないのに対し、 $\mathrm{Zn}$ 量の依存性は明瞭である。Figure 9 には硬さ変化を

$\mathrm{Zn}$ 量および dpa の関数として図示した。この図から照射 硬化は 0.5dpa までにほとんど飽和すること、 Zn は硬化 の照射量依存性を高フルエンス側にシフトさせることが 分かる。

\section{Discussion}

1. Issues associated with ion irradiation イオン照射については1）損傷分布が不均一であるこ と、2）飛程が短いこと、3）損傷速度が中性子照射に 比べて大きすぎること 等多くの問題点が指摘されてき ているが、ここで簡単にこれら問題点に触れておく。

1）については Fig.5に示すように $2.4 \mathrm{MeV} \mathrm{Cu}^{2+}$ イオン では損傷ピークはさほど鋭いものではなく、飛程平均の $\mathrm{dpa}$ はピーク dpa の 70\% 程度であるから、飛程までの範 囲で大まかに一定と考えることは著しく合理性を損なう 
ことにはならない。

2) 飛程が短く機械的強度の評価が可能かについて問 題提起がされるが、本実験では低荷重の試験機を用いて おり、圧痕深さは飛程の1/5程度に留まっている。この ような条件が満足されている場合には、硬さの值は圧痕 深さの 5 倍程度、すなわちほほ飛程までの深さの平均硬

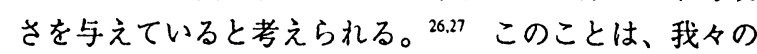
グループの $\mathrm{Fe}-\mathrm{Cu}$ 合金のイオン照射実験でも確かめられ ている。 ${ }^{28}$

3 ）損傷速度は中性子照射に比べて数桁大きく、問題 点は残るが、一方でイオン照射は他の照射条件を変えず に損傷速度を 2 ～ 3 桁の範囲で変えることができるので 将来の検討課題と考える。

\section{Synergistic effect of displacement and nuclear transmutation}

III 章で述べたように、Fabritsievらによれば、約 150

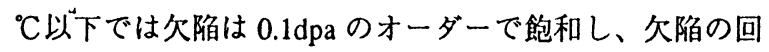
復はほとんど起こらず、電気抵抗の照射欠陥寄与分と核 変換生成物の寄与が加算的であることが示された。この 加算性は、約 $250^{\circ} \mathrm{C}$ 以上の欠陥回復温度領域では成り立 たなくなることが示さ机ている。このことは、少なくと も高温では偏析など、欠陥と核変換生成元素との相互作 用が存在することを示している。我々の結果はこのこと をさらに補強するデータを提供しているものと考えられ る。

非照射試料の硬さは Ni 量にはほとんど依存しないが $\mathrm{Zn}$ 量には明暸に依存している。Table 4 は $\mathrm{Cu}, \mathrm{Ni}, \mathrm{Zn}$ の 原子半径を示すが、 $\mathrm{Ni}$ は $\mathrm{Cu}$ とあまり違わない原子半径 をもち、 $\mathrm{Cu}-\mathrm{Ni}$ 二元系が全率固溶であることに現れてい るように固溶硬化はあまり大きくないことが予想される。 一方、 $\mathrm{Zn}$ は $\mathrm{Cu}$ よりもかなり大きな原子半径をもつ原子 で、空格子点と大きな相互作用をもつことが期待され、 粒界からの欠乏現象 ${ }^{15}$ や、空格子点易動度の低下による 照射硬化の高フルエンス側へのシフトなどを合理的に説 明することができる。また、Znはいわゆる鈴木効果

（化学的相互作用）によって拢張転位と強く相互作用す ることが知られており、29これにより非照射試料の硬さ の $\mathrm{Zn}$ 濃度依存性が説明される。

さらに、Fig.9に示されているように、純銅および $\mathrm{Cu}-\mathrm{Ni}$ 合金は照射とともに硬さは早い立ち上がりを示し、 〜0.5dpaではほとんど飽和する。Ni は Undersized の原子 なので、混合亜鈴型格子間原子を作る可能性があり、そ の拡散で生じる Ni クラスターが格子間原子型転位ループ の核になることが考えられる。15 また、純銅の場合、 カスケードコラプスによって容易に空格子点クラスター

TABLE 4. Atomic radii for $\mathrm{Cu}, \mathrm{Ni}, \mathrm{Zn}$.

\begin{tabular}{llll}
\hline Element & $\mathrm{Cu}$ & $\mathrm{Ni}$ & $\mathrm{Zn}$ \\
\hline Atomic radii(nm) & 0.128 & 0.125 & 0.137 \\
\hline
\end{tabular}

ができるので、フレンケル欠陥対の再結合が妨げられ、 これが格子間原子型ループ形成を助長することが考えら れる。1 8

核変換生成物の効果は ITER 程度のフルエンスでは無 視できるとする考えもあったが、上述の検討から考えて、 かなり少ないフルエンスから考慮しなくてはならないと 考える。Eldrup と Singh は OFHC-Cuを DR-3 炉で $100^{\circ} \mathrm{C}$ で 0.3dpa まで照射し電気抵抗変化を測定しているが、 電気伝導度低下は約 $12 \%$ で、電気抵抗増加にして $2 \mathrm{n} \Omega \mathrm{m}$ に相当する。30 この場合の熱中性子フルエン スは $4.2 \times 10^{24} \mathrm{~m}^{-2}$ なので、II B 節に述べたFabritsiev ら の $\mathrm{K}$ の值 $\left(\mathrm{K}=3.5 \mathrm{n} \Omega \cdot \mathrm{m} / 10^{25} \mathrm{n} / \mathrm{m}^{2}\right)$ を用いると、核 変換生成物の笴与は $1.5 \mathrm{n} \Omega \mathrm{m}$ となり、僅か $0.3 \mathrm{dpa}$ と いう低照射量でもその影響は無視できないことは明らか である。これらはすべて原子炉中性子照射等の結果であ り、今後、中性子スペクトル、フルエンス、照射温度、 損傷速度等の重要なパラメータにつき包括的な研究を行 う必要がある。

\section{Some remarks on dezincification}

互鉛を含む銅合金の融解中に巠鉛が飛散し、成分調整 が困難なこと、熱処理時に互鉛が揮発する可能性がある ことを述べたが、特に後者の影響を評価するための予備 的検討を行った。巫鉛の蒸気圧は極めて高く $400^{\circ} \mathrm{C} て ゙$ 0.1 torr 、 $200{ }^{\circ} \mathrm{C} て ゙ も ~ 10^{-6}$ torr なので検討の必要があろう。 極端な条件として $\mathrm{Cu}-40 \% \mathrm{Zn}$ 合金を用い、種々の温度で 種々の時間保持した後の重量変化測定では、〜 $500{ }^{\circ} \mathrm{C}$ 以 上で㝷鉛蒸発に起因すると思われる重量損失が認められ た。この現象のプラズマに対する影響については今後さ らに検討を進める予定である。

\section{Effect on thermal stress parameter}

ヒートシンク材が拘束されている条件で熱負荷がかかっ た場合、発生する熱応力、 $\sigma_{\mathrm{t}} 、$ は、熱伝導度を $\kappa 、 ヤ$ ング率をE、線膨張係数を $\alpha$ : 熱流束をq、試料厚さを $\mathrm{t}$ として

$$
\sigma_{\mathrm{th}}=\mathrm{E} \alpha \mathrm{qt} / \kappa,
$$

と表される。高熱流束機器材料の評価指標としてょく用 いられる熱心力パラメータ, $\mathrm{M}$ ，は $\sigma_{\mathrm{y}}$ を降伏応力、レを ポアソン比として

$$
\mathrm{M}=\sigma_{\mathrm{y}} \kappa(1-\nu) / \alpha \mathrm{E},
$$

と表せるが、この 2 式を用いて、熱流束に伴う熱応力に よって材料が降伏しない限界の熱流束 $\mathrm{q}_{\max }$ は

$$
\mathrm{q}_{\max }=\mathrm{M} /(1-\nu) \mathrm{t} .
$$

で与えられる。これらの式からヒートシンク材としては 熱伝導度と降伏応力のような力学特性が如何に重要かが 了解されよう。Figure 10 に核变換生成物により劣化した 熱伝導度が熱応力パラメータを如何に低下させるかを示 す。 


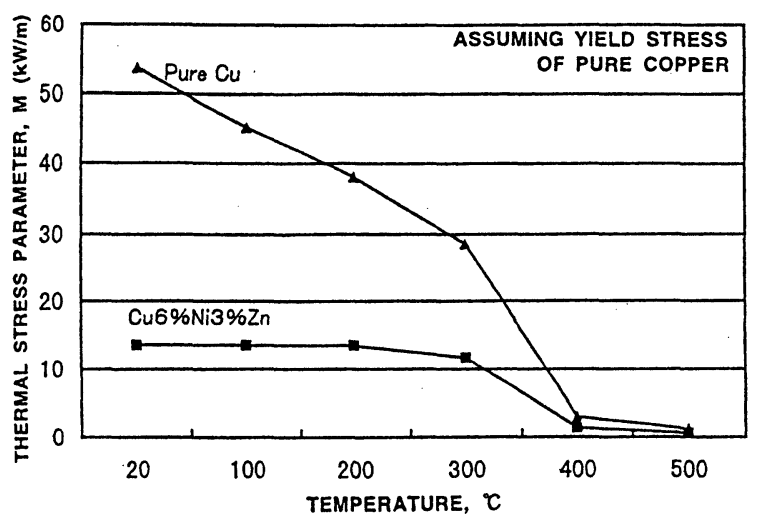

FIG.10. Thermal stress parameter as a function of temperature calculated from thermal conductivity(FIG.8) and published yield stress.

\section{v. CONCLUSIONS}

（1）核融合炬高熱流束機器ヒートシンク材としての銅 合金の照射効果について既往の知見を調查し、まとめた。 （2）ヒートシンク材としては、酸化物分散強化型ある いは析出強化型の高力高伝導銅合金が用いられるが、こ れらは基本特性として約 $300^{\circ} \mathrm{C}$ 以上で軟化するので、そ れ以下の温度領域でしか使用できな。

（3） $300^{\circ} \mathrm{C}$ 以下での中性子照射環境下での問題点は、 いわゆる低温照射脆化と熱伝導度少化、さらに条件によっ ては照射下クリープ、ボイドスエリングが問題となる。

（4）低温照射脆化は約 $150^{\circ} \mathrm{C}$ 以下で使用される場合顕 著となることから、いわゆる設計ウインドウはほほ150 〜300 $\mathrm{C}$ の範囲に限られる。

（5）熱伝導度低下の機構として、はじき出し損伤およ

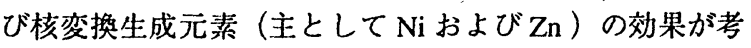
えられる。これらの效果は必ずしも加算的ではなく、相 乗効果が重要となることを示す複数の証拠がある。

（6）はじき出し/核变換相乗効果を調べることを目的と した筆者の研究室の実験的研究のこれまでの成果をまと めた。

（7）純銅における核変換を模擬した $\mathrm{Cu}-\mathrm{Ni}-\mathrm{Zn}$ 合金を融 製し。これら試料の非照射の電気抵抗はほほ濃度、組成 について加算的と考えられる。

（8） Cu-Ni-Zn 合金の非照射のマイクロ硬さは明瞭な $\mathrm{Zn}$ 濃度依存性を示すが、Ni 濃度依存性はあまり顕著で
はない。

（9）室温で $2.4 \mathrm{MeV} \mathrm{Cu}^{2+}$ イオン照射を行うと、硬さ変 化は中性子照射の場合と同様に〜0.5dpa まででほとんど 飽和する。しかし、照射による硬さ変化は Zn 添加ととも に遅滞し、高フルエンス側にシフトする。

（1０）以上を総合すると、Ni 原子は混合亜鈴型格子間 原子を形成し、高い易動度で搪散して格子間原子型転位 ループの核形成を促進するとともに、粒界、ボイド等に 照射誘起偏析を引き起こす。これに対し、 Zn は非照射 状態でも鈴木効果により搪張転位に集まり硬化をもたら す. 照射下では、原子半径が大きなため、空格子点と対 を作り、空格子点拡散を遅滞化し、粒界からは矢そする。

\section{ACKNOWLEDGEMENTS}

九州大学応用力学研究所吉田直亮教授にはイオン加速 器の利用を可能にして戴き、また、銅合金の照射損傷に 関し討論を戴いたことに感謝する。同研究所の渡辺英雄 助教授、森下和功博士（現京都大学エネルギー理工学研 究所助教授）、吉田研究室の大学院生の皆さんには実験 遂行上大変お世話になった。試料の融製、加工、調製、 分析等に関しては、東京大学工学部システム量子工学科 荒井良夫氏に全面的にお世話になった。

東海大学大学院生久留井敦上（現東大大学院）、森田憲 二（現（財）発電技検）、古沢裕主、市川正一、稲葉太 郎、長谷川忠之、学部学生石山 実 (現 (株) 京浜コ一 ポレーション）の諸君には電気抵抗測定、イオン照射と 硬さ測定などに参加して戴いた。ここに記して謝意を表 する。

\section{REFERENCES}

1 J. W. Davies and G. M. Kalinin, J. Nucl. Mater. 258-263(1998) 323.

2 G. M. Kalinin and R. Matera, J. Nucl. Mater. 258-263(1998) 345.

${ }^{3}$ F. A. Garner, J. R. Greenwood and F. M. Mann, Fusion Reactor Materials Semiannual Progress Report, DOE/ER-0313-13(1992) 42.

4 T. Kondo, J. Nucl. Mater. 258-263(1998) 47.

5 T. Muroga, S. Onuki, F. A. Garner and S. J. Zinkle, J. Nucl. Mater. 258-263(1998) 130.

6 J. L. Boutard, J. Nucl. Mater. 174(1990) 240.

7 S. A. Fabritsiev, S. J.Zinkle, B. N. Singh, J. Nucl. Mater. 233-237(1996)127.

8 S. A. Fabritsiev, A. S. Pokrovsky, S. J. Zinkle,D. J. Edwards, J. Nucl. Mater. 233-237 (1996)513.

9 S. A. Fabritsiev, A. S. Pokrovsky, D. J. Edwards, S. J. Zinkle, J. Nucl. Mater. 258-263(1998) 1015.

${ }^{10}$ D. J. Alexander, S. J. Zinkle, A. F. Rowcliffe, J. Nucl. 
Mater. 271-272(1999) 429.

1 S. Tatinen, M. Pyykkonen, P. Karjalainen-Roikonen, B. N. Singh, P. Toft, J. Nucl. Mater. 258-263(1998) 1010.

12 S. A. Fabritsiev, A. S. Pokrovsky, D. J. Edwards, S. J. Zinkle, A. F. Rowcliffe, presented at ICFRM-9, Oct. 1999, J. Nucl. Mater. to be published.

13 S. A. Fabritsiev, A. S. Pokrovsky, S. J. Zinkle, A. F. Rowcliffe, D. J. Edwards, F. A. Garner, V. A. Sandakov, B. N. Singh, V. R. Barabash, J. Nucl. Mater. 233-237 (1996) 526

14 T. Muroga, N. Yoshida, J. Nucl. Mater. 212-215(1994) 266.

15 D. J. Edwards, F. A. Garner, L. R. Greenwood, J. Nucl. Mater. 212-215(1994) 404.

16 T. Muroga, H. Watanabe, N. Yoshida, J. Nucl. Mater. 258-263(1998) 955.

17 L. R. Greenwood, B. M. Oliver, F. A. Garner, T. Muroga, J.Nucl. Mater. 258-263(1998) 985.

18 T. Muroga, T. Matue, H. Watanabe, N. Yoshida, in Effects of Radiation on Materials, 18 th Int. Symp. ASTM STP 1325, R. K. Nanstad, M. L. Hamilton, F. A. Garner, A. S. Kumar Eds. (ASTM, W.Conshohocken, PA, 1999) 991.

19 S. Ishino, A. Kurui, S. Ichikawa, T. Inaba, T. Hasegawa, reported at ICFRM-9, Colorado Springs, Oct. 1999, tobe published in J. Nucl. Mater.

20 H. Iwakiri, H.Wakimoto, H. Watanabe and N. Yoshida, J. Nucl. Mater. 258-263 (1998) 873.

21 S. Ishino, A. Kurui, H. Furusawa, K. Morita, N. Yoshida, Annual Progress Report of the Collaborative Research for FY 1997, No.1, March 1998 (Inst.Appl. Mechanics, Kyushu Univ.) pp.125-127.
${ }^{22}$ S. Ishino, A. Kurui, H. Furusawa, K. Morita, S. Ichikawa, T. Inaba, T. Hasegawa, N. Yoshida, K. Morishita, Annual Progress Report of the Collaborative Research for FY 1998, No.2, March 1999 (Inst.Appl. Mechanics, Kyushu Univ.) pp.133-136.

${ }^{23}$ See for example, Science Year Book, ed. by National Astronomical Observatory, 68 th Edition (Maruzen, Tokyo, 1995) p.527 (in Japanese).

${ }^{24}$ C. Y. Ho, M. W. Ackerman, K. Y. Wu, T. N. Havill, R. H. Bogaard, R. A. Matura, S. G. Oh, H. M. James, J. Phys. Chem. Ref. Data, 12(2)(1983) 183.

25 S. J. Zinkle and S. A. Fabritsiev, Copper Alloys for High Heat Flux Applications, Atomic and Plasma Materials Interaction Data for Fusion (Supplement to Nuclear Fusion) 5(1994) 163.

${ }^{26}$ T. Suzuki and T. Ohmura, Jap. J. Tribology, 40(3) (1995); H. Iwakiri, H. Watanabe and N. Yoshida, Rep. Res. Inst Appl. Mech. Kyushu Univ. 82(1997) 197.

${ }^{27}$ H. Iwakiri, H.Wakimoto, H. Watanabe and N. Yoshida, J. Nucl. Mater. 258-263 (1998) 873.

${ }^{28}$ K. Morita, Master of Engineering thesis, Tokai University (1999), to be published.

29 H. Suzuki, Sci Rept. Res. Inst. Tohoku Univ. A4(1952) 455.

${ }^{30}$ M. Eldrup and B. N. Singh, J. Nucl. Mater. 258-263 (1998) 1022.

石野 琹 (いしのしおり)：工学博士 東海大学工学部原子力工学科教授 専攻分野：原子炉・核融合材料、 特に照射損傷、格子久宿、 所属学会 : 日本原子力学会、 日本金属学会、日本物理学会、 ブラズマ・核融合学会、 ASTM, MRS. 